\title{
Egg capsules of the raspthorn sandskate, Psammobatis scobina (Philippi, 1857) (Rajiformes, Rajidae)
}

\author{
Cápsulas ovígeras de la raya pequén, Psammobatis scobina (Philippi, 1857) \\ (Rajiformes, Rajidae) \\ Francisco Concha ${ }^{1}$, Sebastián Hernández ${ }^{2}$ and María Cristina Oddone ${ }^{3}$ \\ ${ }^{1}$ Facultad de Ciencias del Mar y de Recursos Naturales, Universidad de Valparaíso, Valparaíso, Chile. \\ Casilla 5080 Reñaca, Viña del Mar, Chile \\ ${ }^{2}$ School of Biological Sciences, Victoria University of Wellington, PO Box 600, Wellington 6140, New Zealand \\ ${ }^{3}$ Secretaria Especial de Aqüicultura e Pesca da Presidência da República, Esplanada dos Ministérios, \\ Bloco D, $2^{\circ}$ andar, Sala 238, CEP: 70.043-900, Brasília, DF, Brazil \\ francisco.concha@gmail.com
}

Resumen.- En diciembre de 2005 se recolectaron cápsulas ovígeras de dos hembras de Psammobatis scobina, capturadas en Caleta Montemar, Chile central (32 ${ }^{\circ} 57^{\prime}$ 'S $-71^{\circ} 33^{\prime} \mathrm{W}$ ). La superficie de las cápsulas fue suave y finamente estriada, de color café y translúcida. Además presentaron la típica forma de barril. La longitud central fluctuó entre 35,25 mm y 38,45 mm y su ancho varió entre 25,91 mm y 27,94 mm. La cara dorsal es convexa con respecto a la ventral. Los cuernos anteriores son más cortos que los posteriores, se orientan hacia el interior y se estrechan hasta adquirir forma de zarcillos hacia las puntas. Los zarcillos laterales resultaron ser un carácter diagnóstico entre especies del mismo género en Chile. Esta es la primera descripción de las cápsulas ovígeras de $P$. scobina, especie endémica para las costas del sur de Sudamérica.

Palabras clave: Chondrichthyes, reproducción, oviparía simple

\section{Introduction}

Three species of sandskates of the genus Psammobatis (Günther, 1870) have been reported for the Southeast Pacific. The raspthorn sandskate, Psammobatis scobina (Philippi, 1857), is an endemic species ranging from

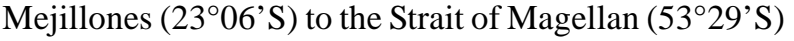
(Pequeño \& Lamilla 1985, Lamilla et al. 2005). The shortfin sandskate, P. normani (McEachran, 1983) and the smallthorn sandskate, $P$. rudis (Günther, 1870), are both distributed between Isla Guafo (4336's) and the Strait of Magellan and southwest Atlantic (McEachran 1983, Pequeño \& Lamilla 1985, Lamilla et al. 2005).

There is little information on the Psammobatis species, with the exception of Braccini \& Chiaramonte (2002a, b) on Psammobatis extenta and Mabragaña \& Cousseau (2004) on $P$. rudis and $P$. normani. These references contain important descriptions of the morphologic and morphometric features of these species in the south western Atlantic.

Some authors provided diagrams or photographs of the rajid egg capsules (Bor et al. 2003, Ebert 2005), but most with limited information on the measurements of the egg capsules, which is crucial for species identification. Another source of data is deposited in museums or collections, but these samples are not enough for comparative studies based on egg capsules descriptions (Gomes \& de Carvalho 1995).

The description of the elasmobranch egg capsules is an important source of systematic information on the different rajid species, apart from their reproductive biology and also distribution (Ishiyama 1958, Hubbs \& Ishiyama 1968, Oddone et al. 2004).

The aim of this work is to provide the first description of the egg capsules of the south eastern Pacific's raspthorn sandskate, $P$. scobina.

\section{Material and methods}

Four egg capsules of $P$. scobina were available for this study. These samples were obtained from two female specimens captured as bycatch from the artisanal trawl fishery off Caleta Montemar (32 $57^{\prime}$ 'S, $71^{\circ} 33^{\prime} \mathrm{W}$ ) on December 2005. This fishery was targeting Paralichthys microps and Cilus gilberti at a depth of about $50 \mathrm{~m}$. The first pair of egg capsules was removed from the uteri once caught. The second pair was laid by a female kept in captivity for six days before obit. The egg capsules were preserved in 70\% ethanol and deposited in pairs in the Museo Nacional de Historia Natural, at Santiago, Chile (MNHNC P.7310 and MNHNC P. 7311). 


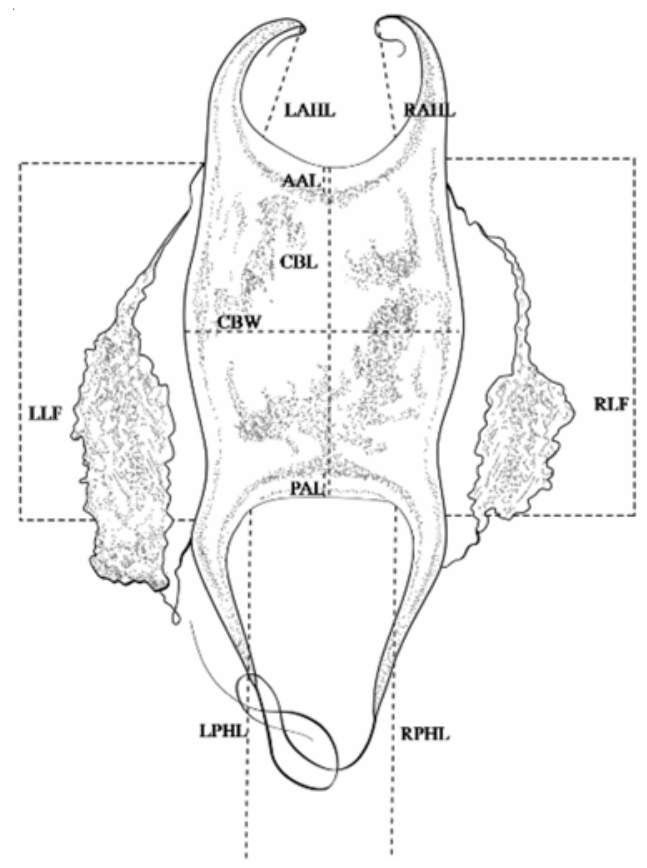

Figure 1

\section{Measurements and terminology used for egg capsules of} Psammobatis scobina

Mediciones y terminología usada para las cápsulas ovígeras de Psammobatis scobina

The measurements taken on each egg capsule included the central body length (CBL), central body width (CBW), anterior apron length (AAL), posterior apron length (PAL), right lateral fibrils insertion points distance (RLF), left lateral fibrils insertion points distance (LLF), right anterior horn length (RAHL), left anterior horn length (LAHL), right posterior horn length (RPHL), and left posterior horn length (LPHL). Measurements were done with the aid of a calliper to the nearest $0.01 \mathrm{~mm}$, following Treloar et al. (2006) (Fig. 1).

\section{Results}

All fresh egg capsules collected contained a single ovum. Capsules were brown, translucent and barrel-shaped with a soft and finely striated surface. In the lateral view, the capsules' dorsal faces were convex and the ventral faces were flat (Fig. 2).

The anterior horns of the egg capsules extracted from the uteri were still in contact with their respective nidamental gland, since they were almost completely formed. Egg capsules were dorsoventrally flattened at the base, stretching towards the tips. The inwardly orientated

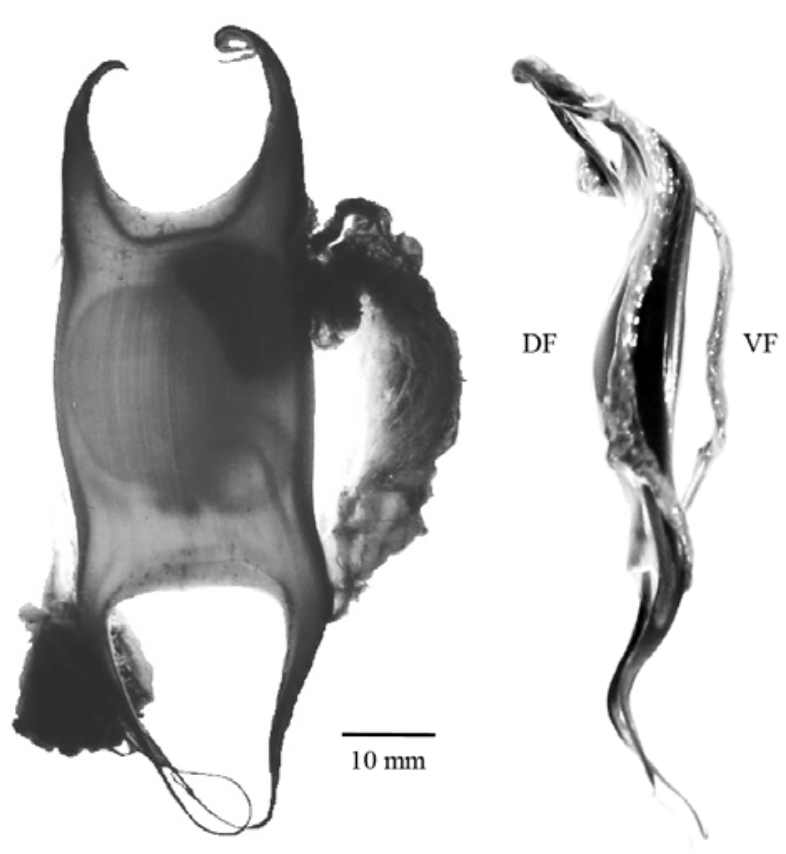

Figure 2

Dorsal (left) and lateral (right) views of a fresh egg capsule of Psammobatis scobina (P.7310). Dorsal and ventral faces (DF and VF respectively) are indicated in lateral view

Vistas dorsal (izquierda) y lateral (derecha) de la cápsula del huevo de Psammobatis scobina (P.7310). Las caras dorsal y ventral (DF y VF respectivamente) se indican en la vista lateral

anterior horns were shorter than posteriors, adding about $40 \%$ to the central body length of the capsule. The posterior horns became tendril-like at the tips. The tendrils were longer than the central body length of the capsule and did not reach the cloaca while the anterior horns were still in contact with the nidamental gland.

Filamentous structures were observed coming up laterally on each side of the egg capsule (Figs. 1 and 2). These lateral fibrils rise anteriorly up from the margin of the anterior apron. The posterior attachment point of the structure is behind the posterior apron margin. Lateral fibrils are constructed of many thin fibres that are grouped together. These are smooth near the attachment points, and coiled and entangled in the middle. Lateral fibrils were not in contact with the body of the capsule, except at the anterior and posterior attachment points. Measurements taken on the four egg capsules are presented in Table 1. 
Table 1

Measurements of the egg capsules of Psammobatis scobina taken from the females (P.7310 and P.7311)

Mediciones de las cápsulas ovígeras de Psammobatis scobina tomadas de las hembras (P.7310 y P.7311)

\begin{tabular}{lrrrr}
\hline Morphometric description & \multicolumn{5}{c}{ Measurements (mm) } \\
\hline Central body length (CBL) & 38.45 & 37.43 & 35.53 & 35.25 \\
Central body width (CBW) & 27.94 & 27.47 & 25.91 & 26.70 \\
Anterior apron length (AAL) & 3.49 & 3.62 & 3.02 & 3.10 \\
Posterior apron length (PAL) & 4.00 & 4.53 & 4.56 & 4.63 \\
Right lateral fibrils insertion points distance (RLF) & 46.60 & 48.11 & 37.24 & 36.16 \\
Left lateral fibril insertion points distance (LLF) & 44.50 & 47.47 & 38.73 & 35.90 \\
Right anterior horn length (RAHL) & 11.18 & 12.71 & 15.39 & 14.43 \\
Left anterior horn length (LAHL) & 10.42 & 13.5 & 13.15 & 15.61 \\
Right posterior horn length (RPHL) & 51.79 & 53.1 & 21.51 & 21.51 \\
Left posterior horn length (LPHL) & 52.29 & 59.29 & 23.84 & 19.51 \\
\hline
\end{tabular}

\section{Discussion}

Elasmobranch egg capsules, which consist of a multilaminated proteinic matrix, are secreted by the nidamental gland and then laid in the marine environment (Oddone 2005). P. scobina displays simple oviparity, since only one egg capsule per uterus can be found. The capsule cover layer, translucent when extracted from the oviducts, has a single yolk sac which will serve as feeding source for one embryo, like previously noted by Clark (1922), Oddone et al. (2004) in Rajidae, and by Gomes \& de Carvalho (1995) and Hernández et al. (2005) in Scyliorhinidae. The colour and shape of the egg capsules were common features among other rajids, as has been observed by other authors (Clark 1922, Hubbs \& Ishiyama 1968, Templeman 1982, Luer \& Gilbert 1985, Leonard et al. 1999, Oddone \& Vooren 2002 and Ebert 2005).

Recently laid egg capsules are different in appearance than those that have already spent several days in the marine environment. The surface becomes darker and less translucent in the latter, as also it has been documented in scyliorhinids by Gomes \& de Carvalho (1995) and Hernández et al. (2005). These variations in the colour of the capsules suggest that capsule colour itself is not recommended as a taxonomic characteristic for specific identification. Colour may also vary within the same species.

The finely striated surface of the egg capsules of $P$. scobina, has been reported in other species, such as Raja maculata, R. naevus, $R$. undulata (Clark 1922), $R$. garmani (McEachran 1970), Psammobatis rudis and $P$. normani (Mabragaña \& Cousseau 2004). Ishiyama (1958) suggested that different kinds of surfaces on the egg capsules would be an adaptation to contribute to developing embryo protection in a given environment. Nevertheless, the surface striation pattern is not necessarily associated with some specific environmental conditions such as temperature or depth. Hence, smooth surfaces can be seen in species inhabiting diverse habitats.

Posterior horns, longer than the anteriors, may represent an efficient attachment tool for fixing the capsule to algae or debris. Oddone \& Vooren (2002) argued that the notable elongation of tendril-like horns of Sympterygia acuta would be an adaptative response for surf-aggregated debris. In $P$. scobina elongated posterior horns were observed, though not as long as those reported for the genus Sympterygia in the Southwest Atlantic by Oddone \& Vooren (2002) and for S. brevicaudata and S. lima in the southeast Pacific (Concha et al. in prep.). The tendrils of S. brevicaudata and S. lima were firmly attached to the tendrils of other capsules in algae or debris, forming dense coils very difficult to unleash.

Lateral fibrils have not been recorded for any south eastern Pacific rajid species. These structures were named by other authors as fibres (Clark 1922, 1927), fibrils (McEachran 1970), attachment fibres (Ebert 2005, Treloar et al. 2006 and Ebert \& Davis 2007) or adhesion fibrils (Oddone et al. 2006). As the names suggest, they observed that these fibrils serve a functional role as fixing structures. These fibres have been reported previously for Raja spp. (Clark 1922, Ebert \& Davis 2007), Dipturus oxyrhinchus (Clark 1927), Raja garmani (McEachran 1970), Bathyraja parmifera, B. trachura (Ebert 2005), B. aleutica and B. kincaidii (Ebert \& Davis 2007). There is 
a relatively low development of anterior and posterior horns in these species; lateral fibrils were considered as the main substratum fixation tool. On the other hand, Psammobatis normani and P. rudis do not present lateral fibrils (Mabragaña \& Cousseau 2004), and their anterior and posterior horns are very similar in size to those recorded for P. scobina in this work. In situ observations are needed to aid in the understanding of the functional role of these structures. The description of the egg capsules of $P$. scobina will contribute to taxonomic differentiation among Psammobatis species, and will aid in defining its distribution. This type of study could be extended to other batoids or selachians with similar reproductive habits.

\section{Acknowledgments}

Authors thank to fishermen of Caleta Montemar for their valuable collaboration and to friends, colleagues and anonymous referees who helped improve this manuscript.

\section{Literature cited}

Bor P, M van Oijen \& C Magenta. 2003. The egg capsule of the coral cat shark, Atelomycterus marmoratus (Bennett, 1830) (Chondrichthyes: Scyliorhinidae). Zoologische Mededelingen, (Leiden) 77: 325-330.

Braccini C \& G Chiaramonte. 2002a. Biología de la raya Psammobatis extenta (Garman, 1913) (Batoidea: Rajidae). Revista Chilena de Historia Natural 75: 179-188.

Braccini C \& G Chiaramonte. 2002b. Reproductive biology of Psammobatis extenta. Journal of Fish Biology 61: 272-288.

Clark R. 1922. Rays and skates (Raiae). $\mathrm{N}^{\circ} 1$. Egg capsules and young. Journal of the Marine Biological Association of the United Kingdom 12(4): 577-641.

Clark R. 1927. Rays and skates. $\mathrm{N}^{\circ} 2$. Description of embryos. Journal of the Marine Biological Association of the United Kingdom 14: 661-684.

Ebert D. 2005. Reproductive biology of skates, Bathyraja (Ishiyama), along the eastern Bearing Sea continental slope. Journal of Fish Biology 66: 618-649.

Ebert D \& C Davis. 2007. Descriptions of egg cases (Chondrichthyes: Rajiformes: Rajoidei) from the eastern North Pacific. Zootaxa 1393: 1-18.

Gomes U \& M de Carvalho. 1995. Egg capsules of Schroederichthys tenuis and Scyliorhinus haeckelii (Chondrichthyes, Scyliorhinidae). Copeia 1995(1): 232-236.

Hernández S, J Lamilla, E Dupré \& W Stotz. 2005. Desarrollo embrionario de la pintarroja común Schroederichthys chilensis (Guichenot, 1848) (Chondrichthyes: Scyliorhinidae). Gayana 69(1): 191-197.
Hubbs C \& R Ishiyama. 1968. Method for the taxonomic study and description of skates (Rajidae). Copeia 1968(3): 483-491.

Ishiyama R. 1958. Observations on the eggs-capsules of skates of the family Rajidae, found in Japan and its adjacent waters. Bulletin of the Museum of Comparative Zoology at Harvard College 118(1): 1-24.

Lamilla J, E Acuña, M Araya, M Oliva, I Kong, JC Villaroel, S Hernández, F Concha, R Vögler, C Bustamante \& E Mutschcke. 2005. Lineamientos básicos para desarrollar el plan de acción nacional de tiburones. Informe Final. Proyecto FIP 2004-18: 1-621.

Leonard J, A Summers \& T Koob. 1999. Metabolic rate of embryonic little skate, Raja erinacea (Chondrichthyes: Batoidea): The cost of active pumping. Journal of Experimental Zoology 283: 13-18.

Luer C \& P Gilbert. 1985. Mating behavior, egg deposition, incubation period, and hatching in the clearnose skate, Raja eglanteria. Environmental Biology of Fishes 13(3): 161-171.

Mabragaña E \& M Cousseau. 2004. Reproductive biology of two sympatric skates in the south-west Atlantic: Psammobatis rudis and Psammobatis normani. Journal of Fish Biology 65: 559-573.

McEachran J. 1970. Egg capsule and reproductive biology of the skate Raja garmani (Pisces: Rajidae). Copeia 1970(1): 197-199.

McEachran J. 1983. Results of the research cruises of FRV Walther Herwig to South America. LXI. Revision of the South American skate genus Psammobatis Günther, 1870 (Elasmobranchii: Rajiformes, Rajidae). Archiv für Fischereiwissenschaft 34(1): 23-80.

Oddone MC. 2005. Microscopic structure of the egg capsule of Atlantoraja cyclophora (Elasmobranchii: Rajidae: Arhynchobatinae). Biota Neotropica 5: 1-4.

Oddone MC \& CM Vooren. 2002. Egg-cases and size at hatching of Sympterygia acuta in the south-western Atlantic. Journal of Fish Biology 61: 858-861.

Oddone MC, A Marcal \& CM Vooren. 2004. Egg capsules of Atlantoraja cyclophora (Regan, 1903) and A. platana (Günther, 1880) (Pisces, Elasmobranchii, Rajidae). Zootaxa 426: $1-4$

Oddone MC, A Mesa \& AF Ferreira de Amorim. 2006. The egg capsule of Rioraja agassizi (Müller \& Henle) (Elasmobranchii, Rajidae), endemic to the SW Atlantic. Pan-American Journal of Aquatic Sciences 1(2): 43-48.

Pequeño G \& J Lamilla. 1985. Estudio sobre una colección de rayas del sur de Chile (Chondrichthyes, Rajidae). Revista de Biología Marina 21(2): 225-271.

Templeman W. 1982. Development, ocurrence and characteristics of egg capsules of the thorny skate, Raja radiata, in the Northwest Atlantic. Journal of Northwestern Atlantic Fishery Science 3: 47-56.

Treloar M, L Laurenson \& J Stevens. 2006. Descriptions of rajid egg cases from southeastern Australian waters. Zootaxa 1231: 53-68. 